\title{
Moving and handling in the community: The real cost of an informal carer
}

Społeczna kwestia opieki związanej z przenoszeniem i przemieszczaniem pacjentów: rzeczywiste koszty ponoszone przez opiekunów nieformalnych

Jamie Wyton ${ }^{1}$

${ }^{1}$ Institute for Posture, Movement and Handling, Birmingham City University, Faculty of Health, Education and Life Sciences, UK

\section{CORRESPONDING AUTHOR \\ Birmingham City University, Faculty of Health \\ Room SCT 160, City South Campus \\ Westbourne Road, Edgbaston, Birmingham B15 3TN e-mail: Jamie.Wyton@bcu.ac.uk}

\begin{abstract}
STRESZCZENIE SPOLECZNA KWESTIA OPIEKI ZWIAZANEJ Z PRZENOSZENIEM I PRZEMIESZCZANIEM PACJENTÓW: RZEECZYWISTE KOSZIY PONOSZONE PRZEZ OPIEKUNÓW NIEFORMALNYCH

Wstęp. Zaburzenia układu mięśniowo-szkieletowego stanowią główną przyczynę niezdolności do pracy, zwolnień chorobowych oraz utraty wydajności wśród mieszkańców wszystkich krajów Unii Europejskiej.

Cel. Niniejszy artykuł analizuje dostępne dowody wskazujące na obciążenie takimi zaburzeniami opiekunów nieformalnych w Wielkiej Brytanii, a także podkreśla znaczenie szkoleń dotyczących podnoszenia i przemieszczania chorych, które mogą okazać się pomocne dla osób pełniących funkcję takich opiekunów oraz dla ich rodzin.

Podsumowanie. Takie rozwiązania mogłoby zredukować ekonomiczne i społeczne koszty jakie niosą ze sobą zaburzenia układu mięśniowo-szkieletowego.

Słowa kluczowe: opieka nieformalna, problemy zdrowotne opiekuna, urazy układu mięśniowo-szkieletowego
\end{abstract}

\section{ABSTRACT MOVING AND HANDLING IN THE COMMUNIT: THE REAL COST OF AN INFORMAL CARER?}

Introduction. Musculoskeletal disorders (MSDs) are the leading cause of work disability, sickness absence from work, and loss of productivity in healthcare across all the European Union (EU) member states.

Aim. This article examines the available evidence on the economic burden of MSDs on informal carers in the UK and highlights areas of moving and handling practice.

Summary. Such solutions might improve the outcomes for informal carers and their families, as well as reduce the economic costs of MSDs.

Key words: $\quad$ patient handling, musculoskeletal injuries

\section{INTRODUCTION}

Musculoskeletal Disorders (MSDs) are a common and costly problem for people and organisations across Europe and are highly prevalent within the healthcare setting. The Health and Safety Executive (HSE) in the UK highlighted that $37 \%$ of work related injuries were MSD out of a total of 186,000 reported cases [1]. This is due to the unavoidable high risk postures and activities required during daily patient care delivery. The economic and human costs of MSDs are unnecessary as MSDs are preventable. The health of a nation is important for the wellbeing of individuals and society as a whole, but a healthy population is also a prerequisite for future economic productivity.

This case study explores the potential risk to informal carers within the manual handling realm and how the problem of MSD's can be addressed. This was highlighted in a previous clinical role during a house visit where an informal carer had a tracking hoist fitted for her child but had no training to use it so was still manually lifting. The background of the author is within a nursing field, with professional responsibility for patient safety and advocacy. Experience within practice has shown education of exemplary patient handling is vital for family members or informal carers to comprehend to avoid subsequent risk to the patient and themselves. To address this practical sessions are offered at the University in Birmingham to educate and support small groups of informal carers who are faced with the responsibilities of patient handling within the home environment. This opportunity allows the individuals to discuss and work through their concerns regarding any moving and handling practice. A crucial point to consider as these are carers who 
are looking after a relative, without having had any of the formal training given within a healthcare setting.

An increasing number of people with additional physical and mental health needs are being supported by informal carers in the community setting. Informal carers provide unpaid care to relatives at home and they will provide personal care, along with supporting day to day activities of daily living [2]. The UK Census in 2011 [3] highlighted that informal carers equate to 6.5 million people inside of the UK. However, unlike the statistics reported in healthcare workers, the prevalence of MSD in informal carers is not measured. By fulfilling this unpaid carers role, informal carers are helping reduce the burden within the UK National Health Service (NHS), due to the shortage of healthcare workers, therefore, saving an estimated 132 billion pounds per year on social care [4]. It is therefore essential to support informal carers in order to ensure this unpaid healthcare resource is able to continue.

The registered charity Mencap is an initial source of information for informal carers regarding moving and handling practice, however, Wanless and Wanless [5] state that providing an individual with information alone is lacking when compared to participating in a practical sessions allowing an individual to understand and work through any issues around the delivery of daily care. Although part of the role of the posture, movement and handling educator at Birmingham City University (BCU) is to deliver extensive training to undergraduate healthcare professionals, another aspect involves teaching and addressing the requirements of these informal carers. The number of carers regularly attending practical sessions at the University which emphasises the carers need for further information.

An additional issue is the diversity of patients cared for at home. Examples include elderly relatives with various conditions, such as Alzheimer's or dementia; to parents looking after their children that may have life limiting and debilitating conditions. Despite this diversity, there are common themes discussed regarding the daily care tasks. These include but are not limited to feeding, bathing, emotional support and rehabilitation. This support is invaluable for enhancing the quality of life the relative being cared for has, but becomes concerning when the carers feel that their main concern is the care of the patient and not for themselves. This is reflected in practice when carers have moving and handling equipment available in their homes but are apprehensive to use it due to brief explanations of its use, instead favouring what they see as 'straight-forward' lifting techniques, ignorant of the dangers to their own musculoskeletal health.

"I had only a short time training with the hoist...I've been told how dangerous they are, so I'm worried to use it" (Carer A)

Informal carers are not governed by any organisation, which means that if they have any concerns or problems these are not addressed through a proper channel, which means any issues are not reported or seen within the evidence. Therefore, listening to carers when they do have a voice within a safe learning environment is a fundamental aspect of being in the role of a moving and handling edu- cator, even if evidence to support such problems are anecdotal at best due to the limited nature within the literature. Key issues discussed within the training are summarised in Fig. 1.1.

Hoist delivered before any training
Not sure who is giving the training
Lack of confidence when using hoist
No follow up support.

Fig 1.1. Key points (anecdotal).

An area of care frequently highlighted as a concern for carers is that of hoisting. Hoisting in the UK is widespread practice both within the acute and community sectors, supporting and ensuring the safety of the dependant patient when moving by reducing the need for physical handling [6]. A hoist is a vital piece of equipment when promoting independence to an otherwise restricted patient, but it requires knowledge, experience and training to correctly use a hoist. Therefore, it is understandable why informal carers will often opt to not use the hoist if they feel they are not fully trained or competent in its use, have fallen into bad routines or are unaware of the consequences to their own or their relative's safety. Yet this issue is consistently raised. Informal carers are often confused to whom will be delivering training and what will be covered. The issue is further compounded as turnaround for hoists from referral to placement in the property is usually prompt and may lead to the informal carer using the equipment prior to adequate training being implemented, resulting in potential for injury of themselves and their relative.

"I was given a hoist, but had the sling taken off me, as I hadn't had training" (Carer B)

"I was told this is the hoist training" (Carer C on attending moving and handling training)

Consequently, when putting a hoist in the home of a patient, additional needs through training and support need to be addressed to ensure the risk of poor hoisting technique is reduced. Increased frequency of training to informal carers could also provide opportunity to acknowledge problems encountered in practice and increase their ability to challenge poor practice.

"I felt ok using the hoist when I was shown, but quite quickly I had questions and there wasn't anyone to ask" (Carer D)

Paediatric practice is often an overlooked area of care when considering moving and handling techniques. This may be due to the thought that smaller patients require little or no moving and handling care when compared to adult practice. Carers commonly express this when caring for a child - the idea they are small, not very heavy can often force a parent to quickly undertake a task without a risk assessment.

"I didn't feel I had a choice, my child needed the toilet, I had to lift them. That's when my back hurt" (Carer E) 
Without clear risk assessment, MSD is a significant problem seen throughout the ages when practicing handling exercises. Although data on MSD's are unknown for informal carers, within one group session at BCU $(n=12)$ who attended the session, $75 \%$ said they had hurt themselves while undertaking moving and handling activities with their relative. Although this is a small sample size, seen within one variable and open to bias, this is nearly double than the estimated injury rate seen within trained health care professionals[7], possibly mirroring the wider problem of risks facing informal carers.

These key points, show that informal carers are not being supported when handling patients. There is a vast difference to that of a healthcare worker, having to work competently within various legislation in the UK, that ultimately support and guide employees before participating in any moving and handling task [8].

"I have had a hoist delivered, the carers are trained to use it, but I'm not allowed, they are here for 6-8 hours a day, how am I supposed to move my father when there not here?"(Carer F)

In comparison informal carers will not receive such in-depth training and are not protected by the law when handling patients. Considering that informal carers take on this role, the lack of legal protection does not balance with the responsibility taken on, but most importantly this can be addressed through basic moving and handling training. Specific training on a piece of equipment does not offer broad transferable moving and handling skills for the carer. Therefore, the importance of teaching moving and handling skills should underpin the foundations for future experiences to be built upon.

\section{Supply and Demand}

The numbers of formal carers within social care in the UK are low due to healthcare budget cuts which has led to a deficit in government supplied care, consequently informal carers are needed to fill this void. The use of informal carers saves the UK healthcare system approximately 132 billion pounds per year, however the 2015-2016 treasury numbers identify that public spending on health care is at 134.1 billion [9]. The demand placed upon informal carers is colossal due to the lack of support provided, lack of own personal life and will often work $50+$ hours a week. The problem with this is the forecasted numbers of informal carers needed in the future will be higher but the deficit of formal carers is not being improved with such budget cuts in the NHS and an increased reliability on informal carers taking on this role.

\section{The Hidden Statistics}

The numbers of injuries to informal carers are unknown. Even with data, interpretation of the statistics may be skewed due to informal carers not necessarily declaring their role if they do not feel it is a 'work' related injury when looking after someone close to them. We can only look at nursing related injuries and hypothesise that informal carers would be more prone to injury due to being less aware of the risks associated with moving and handling tasks because of limited training and support.
Therefore, it can be assumed that an emphasis on effective training should be of paramount importance.

\section{Who's responsible?}

The ambiguity of who has responsibility for delivering the training for informal carers is a concern. Healthcare professionals have a responsibility and duty of care to train them, as they are the suppliers of the equipment. However, due to pressures seen within services, training is often ignored or overlooked, being restricted to brief 'information' sessions being given by those delivering the equipment often only going through the basic functions of the device, rather than the practicalities of using it. This can lead to the carer using the equipment unsafely and inappropriately, increasing the risk to themselves and the patient.

\section{Secondary costs}

The ultimate cost of a carer injuring themselves will always be unknown, due in part to underreporting and cost cannot always measured in economic terms. By not preparing the informal carers healthcare practitioners and equipment providers will be increasing the risk of injury to the informal carer and the patient. Consequently, there may potentially be the need for a replacement carer to look after the initial cared for family member. If an injury is more severe, then a long-term carer might be needed also for the primary informal carer. However, as it has already been highlighted the supply for carers are limited, thus creating a vicious circle.

At the University we continue to offer support to these members of the community, a session will consist of approximately 10-15 people and are tailored to their needs and can vary session to session. Basic principles of safer handling in relation to posture that are demonstrated include:

1. Maintain a Neutral Spine

2. Use your Legs

3. Don't Twist

4. Keep the Load close

Training and demonstrations of equipment such as hoists, slide sheets and transfer aids is also given.

The overall responsibility for this training should lie with the UK government to support and fund this basic level of training and to fix this problem by setting out a clear pathway of training for an informal carer. Upon identification of an Informal carer within the acute environment, basic levels of moving and handling training should be given through the teaching of fundamentals principles of biomechanics, equipment that will be used should be demonstrated and thorough information should be given with regular contact to support these carers should also be put in place. Voluntary organisations such as Carers UK are important as they provide support for informal carers through the supply of information and additional support. 


\section{SUMMARY}

There is a need for the wider healthcare society to take responsibility and support informal carers as they take the strain off the NHS, but are being let down with lack of support and investment for their safety. By protecting this ever-increasing vulnerable group of people, the aim should be to reduce the secondary cost associated with looking after them if they injure themselves due to a lack of moving and handling knowledge and skills. As more and more informal carers are taking on this role, they should be covered under the same vicarious liability of formal carers. They should still have the same level of moving and handling training as a formal carer with healthcare professionals taking responsibility for support when passing on this role to an informal carer. If we don't improve the level of knowledge, training now it will not be too long before the informal carer also requires care.

\section{REFERENCES}

1. Health and Safety Executive (2015). Health and safety in the health and social care sector in Great Britain, 2014/15. [online] p.9. Available at: http://www.hse.gov.uk/ statistics/industry/healthservices/health.pdf?pdf=health [Accessed 25 Jul. 2017].

2. Carers UK. (2015). Facts about carers 2015 - Policy briefing. [ONLINE] Available at: https://www.carersuk.org/for-professionals/policy/policy-library/facts-aboutcarers-2015. [Accessed 8 August 2017].

3. Office for National Statistics ; National Records of Scotland ; Northern Ireland Statistics and Research Agency (2017): 2011 Census aggregate data. UK Data Service (Edition: February 2017). D0I: http://dx.doi.org/10.5257/census/aggregate-2011-2 This information is licensed under the terms of the Open Government Licence [http://www.nationalarchives.gov.uk/doc/open-government-licence/version/2].

4. Carers UK. (2015). Valuing Carers 2015 - the rising value of carers' support. [ONLINE] Available at: http://www.carersuk.org/for-professionals/policy/policy-library/ valuing-carers-2015. [Accessed 8 August 2017].

5. Wanless S, Wanless SG. Improving training and education in patient handling. Nursing Times. 2011;107 (23): 17- 19.

6. Wanless $S$, Wanless SG. Principles and advice for hoisting residents. Nursing and Residential Care. 2012; 14 (6): 306-310.

7. Health and Safety Executive (2015). Health and safety in the health and social care sector in Great Britain, 2014/15. [online] p.9. Available at: http://www.hse.gov.uk/ statistics/industry/healthservices/health.pdf?pdf=health [Accessed $25 \mathrm{Jul}$. 2017].

8. Health and Safety. Commission Manual Handling Operations Regulations 1992 (as amended). HSE Books, Sudbury; 2016.

9. HM Treasury (2016) UK Public Expenditure Statistical Analyses 2016 [July 2016] HM Treasury.

Manuscript received: 16.04 .2018

Manuscript accepted: 17.05.2018 